\title{
Organizaion of Nigerian Universities and Workers' Productivity
}

\author{
Chika Josephine Ifedili (Phd) and Chidiebele Ifedili \\ Faculty of Education, University of Benin \\ P.O. Box 10073, Ugbowo, Benin City, Edo State, Nigeria \\ E-mail: theifedilis@yahoo.com
}

Received: July 23, 2011

Accepted: August 24, 2011 Published: December 1, 2011

doi:10.5539/res.v3n2p150

URL: http://dx.doi.org/10.5539/res.v3n2p150

\begin{abstract}
The study investigated the organization and management of university system following the outcry among education stakeholders on the height of indiscipline among university workers. The population consisted of all teaching and administrative staff of all the tertiary institutions in the three geo-political zones of Nigerian federation: North-Central, Southeast, and Southwest. From these zones, a sample of two federal, two state and two private universities were randomly selected for the study. A stratified random sampling method was used to select 150 academic staff and 150 administrative staff from each government universities while 50 academic and 50 non-academics were selected from private universities. A total sample of 700 teaching staff (410 males and 290 females) and 700 administrative staff (362 males and 338 females) participated in the study. The data of the study were collected using the questionnaire titled Universities Organization and Workers' Productivity (UOWP). The validity of the questionnaire was done by experts in Education Administration and Planning. The reliability of the instrument was tested using a Split-Half Method. The Correlation Coefficient was corrected by the use of Spearman Brown Formula. The Pearson Product Moment Correlation was .69 and final Spearman Brown Formula yielded 0.82. The statistics used were Z-test and percentage. The major finding was that the way the system is organized and managed has created indiscipline in the system. Based on the finding, the major recommendation was restructuring the system for better productivity.
\end{abstract}

Keywords: Nigerian, Universities, Workers, Productivity

\section{Introduction}

Nigerian universities being formal organizations with highly enlightened individuals within the system, is supposed to be a model organization to other organizations. One expects to see corporation among all staff, sense of punctuality, sense of emotional maturity, due respect for one another, dedicated and highly productive workers, high personal integrity and sense of responsibility.

Presently, jobs have been so much humanized because of the contributions of Modern Theorists. The gesture seems to be effective depending to a greater extent on the discipline of individuals within the system. An organization's survival depends to a greater extent on the willingness of individuals within the system to sacrifice a degree of individuality and to conform to certain behavioral norms. Studies (Ifedili 2011, Hersey, 1965) have shown that Theory Y of McGregor is not applicable in Nigeria. Productivity increases with closed supervision because of cultural differences, level of education and standard of living. Nigeria has multi dimensional culture and this has really affected the attitude and behaviors of the individuals within the system. Many researches (Chegini 2010; Ifedili 2011) have shown that culture of the people has a lot of impact on how the people should be organized and managed for better productivity.

The present non-chalant attitude among Nigeria university workers - /both academics and non-academics is becoming a sort of concern for many stakeholders. The non-academic staff who are supposed to be in the office by eight in the morning, hardly open their offices by nine. Not minding their lateness, when they report and sign in, some low cadre workers among them would disappear to their other private businesses; some middle ones move from one office to another chatting, some top ones who are expected to be controlling the junior ones report at times by eleven under the excuse that they either closed late the previous evening or are held up in the traffic. Files pile up unattended for a long time. There is also fear that Parkinson's Law is at work. The offices 
are filled with more than required non-academic workers that many have little or nothing to do while the academics are short in supply (Ifedili, 2003).

The academic staff are not left out in these unholy behaviors. They go late to their lectures and leave the class room early. Some will not put in their best in their full time jobs but hustle for part time teaching jobs in all the universities in their geographical zones. This affects quality of teaching and learning both at their main job and the part time ones. The lecturers hardly have time for their students. Many of them do not carry out any research which is one of the requirements for promotion. Some stay at one level between five to ten years without producing a paper. They continue to search for monetary gains. Remuneration for university's workers has increased, yet the poor attitude persists.

It is a general notion in Nigeria that government work is nobody's work and therefore does not deserve commitment. The apathy to work among some Nigerians can be traced to the colonial era when indigenous civil servants had very limited growth potentials. As was observed by Nwosu (1977), a seasoned civil servant, that Nigerian workers during the colonial era worked to meet above all, the requirements of the colonial masters. They never obtained the reward which was commensurate with the work well done. Today, despite the fact that the policies and objectives are now being formulated by Nigerians for Nigerian needs and the minimum wage has changed greatly, the colonial attitude persists.

The method of appointments in Nigerian government universities is causing a lot of concern to those who have education at heart. Ifedili (2009), stated that there was suppression of excellence and diligence and promotion of mediocrity in the appointments and promotions in Nigeria federal universities. The universities do not seem to employ based on merit but based on who backs the candidates. The present educational management condones favoritism and nepotism. It will be an understatement to say that approximately fifty percent of workers are employed based on staff relationship or political affiliation or tribe. Many of these have no integrity, not committed and academically and experience wise -not qualified. There are many good job seekers but because there is no godfather to talk for them, they remain unemployed while the wrong people are employed. This type of system breeds lawlessness and low productivity. Many people flout the rules and they cannot be disciplined because they are protected by those who brought them into the system or by their Unions. Some of the managers selected to head various parts of the university are never appointed based purely on merit but on the ground that they would be faithful. This is the reason why many seem to find it difficult to control their subordinates. Levitt (1974) pointed out that the process by which a manager is selected is a critical element in managerial success. This determines talents, competences, attitudes, styles, personality which were appropriate for the task and problems of new situation the worker would enter.

\section{Statement of the Problem}

The university organization is whirling out of control. The much needed discipline among the workers is no more there. The humanization of the university organization has had a negative response in contrary to the ideas of the Behavioral Theorists. Many workers seem to be abusing the gesture and the productivity is highly affected negatively. The appointments of wrong candidates have created problem in organizational goal achievements. The number of administrative staff continues to grow with little or nothing to do thereby creating wastage in the system. There is a need to manage the university organization in such a way that the university becomes a unique model for other organizations.

\section{Research Questions}

The following research questions are raised to guide the study: -

1) Are university workers punctual to work?

2) Are university workers disciplined?

3) Are university workers productive?

4) Do university administrative workers have enough workload?

5) Do university academic workers have enough workload?

6) Are rules and regulations strictly applied in the university system?

7) Are university workers properly supervised?

8) Are disciplinary actions strictly taken against university workers who break the university rules? 


\section{Hypothesis}

The following null hypotheses were raised from the research questions:

HO1 There is no significant difference between the responses of academic and non-academic staff on effectiveness of supervision of university staff.

HO2 There is no significant difference in the responses of academic and non-academic staff on the rate of discipline among university staff.

\section{Significance of the Study}

he study will benefit the government by knowing that the money put into the system is well utilized by policy implementers. The university administration will have fewer problems to solve when the workers are focused and productive. Workers themselves will appear responsible and earn some respect by being serious minded with their jobs. Those who have not been publishing will start for their personal growth. The students will be promptly attended to and also would have the benefit of socializing with the workers for better development. Those who are inhibited by poor organization in the university will unlock their potentials by being mentored by their lecturers who will pay more attention to their full time jobs. Customers to the university will be happy to be attended to promptly. The university system organizationally will have the standard which is obtainable in developed countries.

\section{Methodology}

The research design used was survey. The population consisted of all teaching and administrative staff of all the tertiary institutions in the three geo-political zones of Nigerian federation: North-Central, Southeast, and Southwest. From these zones, a sample of two federal, two state and two private universities were selected by stratified random sampling method for the study. A stratified random sampling method was used to select 150 academic staff and 150 administrative staff from each government universities while 50 academic and 50 non-academics were selected from private universities. A total sample of 700 teaching staff (410 males and 290 females) and 700 administrative staff (362 males and 338 females) participated in the study.

The data of the study were collected using questionnaire. The questionnaire was titled Universities Organization and Workers' Productivity (UOWP). It was made up of two parts - Part A was demographic in nature while Part B contained fifteen questions bothering on staff discipline, staff appointments, staff organization, etc. The validity of the questionnaire was done by experts in Education Administration and Planning. The reliability of the instrument was tested using a Split-Half Method. The Correlation Coefficient was corrected by the use of Spearman Brown Formula. The Pearson Product Moment Correlation was .69 and final Spearman Brown Formula yielded 0.82 . The statistics used for data analysis were Z-test and percentage. The scoring was based on $0-.5$ as very poor; .06 - 1.5 as poor; $1.6-2.5$ as average; $2.6-3.5$ as good and 3.5 and above as excellent

\section{Results}

Answers to Research Questions are on Table 1.

Test of Hypotheses

HO1 The first null hypothesis which states that there is no significant difference between the responses of academic and non-academic staff on the effectiveness of supervision of university staff was analyzed with the data collected from the questionnaire as in Table 2.

From Table 2, the calculated Z-Value at 0.05 -Confidence Level was 1.67 while the Table Value was 1.96 . The null hypothesis that there will be no significant difference between the responses of academic and non-academic staff on the effective supervision of university staff is therefore accepted. Both the academic and administrative agreed that supervision of university workers was of average. However, only $35 \%$ of the respondents agreed that supervision was effective while $65 \%$ had a contrary opinion. As remarked by some respondents, there was too much humanization of university and some staff had gone wild.

HO2 The second null hypothesis which states that there is be no significant difference in the responses of academic and non-academic staff on the rate of discipline among university staff was analyzed with the data from the questionnaire as shown in Table 3.

The calculated Z-Value at 0.05 -Confidence Level from Table 3 is 1.5 while the Table Value is 1.96 . The null hypothesis that there will be no significant difference in the responses of academic and non-academic staff on the rate of discipline among university staff is therefore accepted. Both the academic and non-academic staff agreed that rate of disciple could be said to be average. This means that it was not good enough for an academic organization. Sixty-six percent of the respondents agreed that workers were not disciplined while $34 \%$ opined 
that they were discipline. The area of observance of rules and regulations was rated very poorly. In fact some respondents commented that high rate of lawlessness in the system is the order of the day.

\section{Discussion}

From the analysis of data, it can be said that there is problem in the university organization system. A formal academic organization where human resources should set a pace in matters concerning time consciousness to other non-academic formal organizations, had a disappointing rating of $83 \%$ responses agreeing that workers were not punctual to duties. A further analysis of the data showed that male workers were more punctual than female workers. Sixty-seven respondents opined that non-academic staff did not have enough workload. The inadequate workload by the non-academics might have been responsible for their not being punctual to work because they got involved in other personal business. Although $87 \%$ of the respondents agreed that the academics have enough workload, many were not punctual to work for reasons bestly known to them.

University workers were also found to be indiscipline. This is in terms of integrity, emotional maturity, sense of responsibility etc. Sixty-six percent of the respondents agreed that university workers were indiscipline while only $34 \%$ agreed otherwise. This without doubt can be due to poor supervision and not applying rules and regulations strictly.

From the null hypothesis one, both the academic and administrative staff agreed that supervision of university workers was of average. However, only $35 \%$ of the respondents agreed that supervision was effective while $65 \%$ had a contrary opinion. As remarked by some respondents, there was too much humanization of university and some staff had gone wild. The discipline according to null hypotheses 2 was not good enough for academic organization. Sixty-six percent of the respondents agreed that workers were not disciplined while $34 \%$ opined that they were disciplined. The area of observance of rules and regulations was rated very poorly. In fact some respondents commented that high rate of lawlessness in the system was the order of the day. It is so obvious from Ifedili (2011) that for middle and lower level workers in Nigeria to be productive, there is need for close supervision and use of rules and regulations to control the behaviors of individuals within the system.

\section{Recommendations}

The following recommendations are made for better organization and management of human resources in the university system for better productivity:

- There should proper reorientation of staff by organizing conferences, seminars and workshops for various cadres of workers.

- There should be formalistic impersonality in the appointments and promotions of staff. Merit should be the major criteria. Promotion of mediocrity should be avoided in the system.

- The policy of National Universities Commission should be observed by the application of 1:3 in the employment of academic and non-academic staff.

- All workers who have disobeyed University laws and are querried and warned three times should be relieved of their duties and replaced with prospective good workers.

- The non-academics should be rotated every three years in order to make administration more productive.

- Rules and regulations guiding the organization should be strictly adhered by all.

- There should be workers' assessment by the students.

\section{References}

Chegini, M.G. (2010). The relationship between organizational culture and staff productivity in public organization. Iran: Journal of Social Sciences, 6(1), 127-129.

Hersey, P. (1965). Management of organizational behavior. New Jersey: Prentice Hall Inc.

Ifedili, C.J. (2003). Parkinson's law and the administration of Nigerian universities. Benin City: Nigerian Journal of Admin Science, 6(2), 365-381.

Ifedili, C.J. (2009). Promotion criteria in Nigerian federal universities. Nsukka: Review of Education, 21(1), 124-134.

Ifedili, C.J. (2011). Teachers and administrators perception of McGregor's theories X and $\mathrm{Y}$ in the management of public post primary schools in Nigeria. Journal of Trends in Educational Studies, 5(1\&2), 217-230.

Levitt, T. (1974). The managerial merry-go-round. Harvard Business Review, 52(4), 121. 
Mamizadeh, J. (1997). Impact of organizational culture on its performance. Iran: Tadbir Manage, 61, 38-40.

Table 1. Responses to the research questions

\begin{tabular}{|c|c|c|}
\hline & Positive & Negative \\
\hline 1. Are university workers punctual to work? & $17 \%$ & $83 \%$ \\
\hline 2. Are university workers disciplined? & $34 \%$ & $66 \%$ \\
\hline 3. Are university workers productive? & $41 \%$ & $59 \%$ \\
\hline \multicolumn{3}{|l|}{ 4. Do university administrative workers have } \\
\hline enough workload? & $33 \%$ & $67 \%$ \\
\hline \multicolumn{3}{|l|}{ 5. Do university academic workers have } \\
\hline enough workload? & $87 \%$ & $23 \%$ \\
\hline \multicolumn{3}{|l|}{ 6. Are rules and regulations applied } \\
\hline strictly in the university system? & $38 \%$ & $62 \%$ \\
\hline 7. Are university workers properly supervised? & $35 \%$ & $65 \%$ \\
\hline \multicolumn{3}{|l|}{ 8. Are disciplinary actions strictly taken against } \\
\hline university workers who break the university rules? & $40 \%$ & $60 \%$ \\
\hline
\end{tabular}

Table 2. Test of significant difference in the responses of academic and non-academic staff on the effectiveness of supervision of university staff

\begin{tabular}{|l|l|l|l|l|}
\hline Statistics & Academics & Non-Academics & Calculated Z-Value & Table Value \\
\hline Number & 700 & 700 & & \\
\hline Mean & 1.86 & 1,90 & 1.67 & 1.96 \\
\hline SD & .42 & .47 & & \\
\hline
\end{tabular}

Table 3. Test of significant difference between the responses of academic and non-academic staff on the rate of discipline among the university staff

\begin{tabular}{|l|l|l|l|l|}
\hline Statistics & Academics & Non-Academics & Calculated Z-Value & Table Value \\
\hline Number & 700 & 700 & & \\
\hline Mean & 1.62 & 1.65 & 1.5 & 1.96 \\
\hline SD & .35 & .38 & & \\
\hline
\end{tabular}

